\title{
STRATEGI PEMASARAN BUAH MANGGIS PADA KELOMPOKTANI SINAR MUSTIKA PUSPAHIANG DI KABUPETAN TASIKMALAYA
}

\author{
MARKETING STRATEGY MANGGOSTEEN FRUIT \\ ON THE GROUP SINAR MUSTIKA IN TASIKMALAYA DISTRICT
}

\author{
Ulpah Jakiyah*, Budhi Wahyu Fitriadi \\ Program Studi Agribisnis Universitas Perjuangan, J1 PETA No 177 Tasikmalaya \\ *Email: ulpahjakiyah@unper.ac.id \\ (Diterima 30-11-2021; Disetujui 03-06-2021)
}

\begin{abstract}
ABSTRAK
Buah manggis asal Tasikmalaya memiliki peluang pasar ekspor yang cukup besar. Permintaan ekspor yang tinggi mengakibatkan kelompok tani Sinar Mustika melakukan terobosan baru dengan melakukan sertifikasi organik untuk komoditas manggis. Hal ini dilakukan untuk meningkatkan harga jual dan memiliki kekuatan pasar. Harga jual buah manggis dari setiap lembaga pemasaran memiliki rentang yang cukup tinggi. Sehingga tujuan dalam penelitian ini adalah merumuskan strategi pemasaran manggis yang sesuai melalui konsep bauran pemasaran. Perancangan bauran pemasaran melibatkan kondisi internal dan eksternal kelompok tani Sinar Mustika. Analytical Hierarchy Process (AHP) digunakan dalam menentukan strategi mana yang menjadi prioritas dalam kegiatan pemasaran manggis. Tahapan penelitian yang dilakukan antara lain 1) menghimpun informasi pemasaran komoditas manggis dengan melalui observasi, survei, dan wawancara. 2) menghimpun informasi mengenai keunggulan dan kelemahan kegiatan pemasaran manggis di Kabupaten Tasikmalaya, dan 3) merumuskan strategi pengembangan manggis organic dengan AHP. Pemasaran manggis organik memiliki dua saluran pemasaran dengan melibatkan dua distributor, yaitu PT Java Fresh dan PT Anugrah Lalang Buana. Setiap pelaku pemasaran yang terlibat tidak melakukan perubahan pada manggis, melainkan pemasaran dalam bentuk buah manggis segar. Beradasarkan kondisi internal dan eksternal kelompok tani Sinar Mustika memiliki nilai sumbu X 0,58 dan sumbu Y 0,22 berada pada kuadran 1. Menunjukkan posisi kelompoktani harus terus berkonsentrasi pada pasar saat ini (penetrasi pasar dan pengembangan pasar) dan produk. Sedangkan alternatif strategi berdasarkan AHP bahwa kelompoktani harus melakukan strategi dalam peningkatan kualitas pasca panen dengan nilai bobot tertinggi 0,39 . Oleh karena itu, kelompoktani harus bekerjasama dengan pemerintah setempat dalam penyediaan sumberdaya dalam mengingkatkan kualitas produk dan pengembangan pasar untuk dapat mengurangi risiko terhadap manggis
\end{abstract}

Kata kunci: Analytical Hierarchy Process, Grand Strategy, manggis, pemasaran, strategi

\section{ABSTRACT}

Mangosteen fruit from the city of Tasikmalaya has export market opportunities are quite large. Export demand is high resulting in farmers group Sinar Mustika made a new breakthrough by doing organic certification for mangosteen. This is done to increase the selling price and has the power market. The selling price of the mangosteen fruit from each marketing agencies have a range which is quite high. So the purpose of this research is to formulate a marketing strategy mangosteen tools through the concept of the marketing mix. The design of the marketing mix involves the internal and external conditions, farmers group Sinar Mustika. The method of analysis with AHP (Analitical Hierarchy Process) is used for research in determining which strategy to become a priority in the marketing activities of mangosteen. Stages of the research carried out among others 1) to collect marketing information mangosteen with through observation, survey, and interview. 2) gather information about the advantages and weaknesses of the marketing activities of mangosteen in Tasikmalaya Regency, 3) formulate a strategy for the development of 
mangosteen organic with AHP (Analitical Hierarchy Process). Marketing mangosteen organic has two marketing channels involve two distributors which is PT Java Fresh and PT Anugrah Lalang Buana. Every marketing actors involved do not make changes on mangosteen but marketing in the form of fresh mangosteen. According to the internal and external conditions, farmers group Sinar Mustika have the value of the $X$ axis 0.58 and the $Y$-axis 0.22 is in quadrant 1 . Shows the position of the group must continue to concentrate on the current market (market penetration and market development) and product. While alternative strategies beradasrkan AHP that farmer groups should do the strategy in improving the quality of post-harvest with the highest weight value 0.39. Therefore the group should cooperate with local authorities in the provision of resources in increasing the quality of the product and market development to be able to reduce the risk of mangosteen.

Keywords: analytical hierarchy process, grand strategy, mangosteen, marketing, strategy

\section{PENDAHULUAN}

Pemerintah dalam meningkatkan ekspor komoditas pertanian berdampak pada kegiatan pemasaran manggis di Kabupaten Tasikmalaya. Buah manggis asal Tasikmalaya diekspor ke berbagai negara seperti ke China, Singapura, Brunei, dan Amerika. Keberhasilan ekspor buah manggis merupakan peluang besar bagi masyarakat Tasikmalaya untuk memproduksi dan memasarkannya. Jumlah produksi buah manggis di Kabupaten Tasikmalaya mencapai 345 ton pada tahun 2017 (Dinas Pertanian Kabupaten Tasikmalaya, 2017). Namun, jumlah tersebut belum dapat memenuhi permintaan ekspor sebesar 2.000 ton. Hal ini dikarenakan kualitas manggis belum sepenuhnya dapat memenuhi permintaan ekspor. Sehingga Kelompok Sinar Mustika mengambil langkah untuk melakukan sertifikasi organik untuk meningkatkan kualitas buah dan memiliki kekuatan pasar.

Tujuan penelitian ini adalah mengidentifikasi faktor internal dan eksternal, menentukan posisi pasar kelompoktani, dan menentukan strategi pemasaran manggis organik di Tasikmalaya dan upaya memperbaikinya (upgrading). Penelitian ini diharapkan dapat menjadi bahan bagi peneliti untuk memberikan kontribusi bagi perkembangan usaha pertanian dalam bentuk kebijakan yang dilaksanakan sepenuhnya oleh lembaga tersebut.

\section{METODE PENELITIAN}

Penelitian ini dilakukan pada kelompoktani Sinar Mustika di Kecamatan Puspahiang Kabupaten Tasikmalaya. Pemilihan lokasi dilakukan secara sengaja (purposive sampling) dengan dasar bahwa lokasi ini dekat dengan eksportir manggis. Kegiatan penelitian dilakukan pada bulan AgustusNovember 2020. Cara yang dilakukan dalam memperoleh data antara lain: 1) observasi lapangan dari pengamatan langsung serta melakukan wawancara dengan berbagai pihak yang terlibat di 
dalam Kelompok Tani Sinar Mustika; 2) opini pakar yang disusun dalam matriks IFE dan EFE; 3) Penentuan strategi pemasaran dengan melihat 4P dengan metode AHP. Penentuan sampel ditentukan dengan metode purposive sampling pada responden yang berada di lingkungan Kelompok Tani Sinar Mustika. Responden yang digunakan merupakan responden yang ahli di bidang pemasaran manggis dan kontribusi langsung dengan komoditi manggis.

Jumlah sampel yang dipilih dalam penelitian ini adalah 15 responden dengan berbagai kriteria sebagai berikut:

1. Kontribusi langsung dalam kegiatan pemasaran manggis.

2. Petani responden yang sudah memiliki pengalaman lebih dari 5 tahun.

3. Memiliki data yang akurat.

4. Mampu memberikan informasi yang lengkap dan memahami serta merespon pertanyaan yang berada dalam instrumen kuesioner.

Karakteristik dari manggis organik diidentifikasi menggunakan analisis deskriptif untuk memperoleh gambaran umum dan mendalam mengenai manggis organik yang berada di kelompoktani Sinar Mustika Kecamatan Puspahiang.
Selain itu, melakukan identifikasi peranan para pelaku pemasaran manggis. Beberapa tahapan dalam melakukan formulasi strategi dalam pengambilan keputusan antara lain tahapan pengumpulan input, pemanduan, dan penentuan keputusan strategi.

Tahapan input dengan melihat faktor internal (matriks IFE), faktor eksternal (Matriks EFE), dan grand strategi di kelompoktani Sinar Mustika terhadap produk manggis. Identifikasi faktor internal dan eksternal sebagai masukan dasar untuk merumuskan strategi. Tahapan ini digunakan untuk mengetahui kekuatan (Strength), kelemahan (Weakness), peluang (Opportunity), dan ancaman (Threath) dalam membuat matriks EFE (External Factor Evaluation) dan IFE (Internal Factor Evaluation). Setelah faktor internal dan eksternal diketahui, maka dilakukan pembobotan dengan pengukuran skala ordinal oleh responden yang ahli. Skala ordinal merupakan skala yang tidak hanya menyatakan kategori melainkan menyatakan peringkat construct yang diukur (Sugiyono, 2014).

Tahapan selanjutnya adalah pemanduan atau Matching Stage dengan analisis Grand Strategy. Hasil dari pemanduan ini digunakan untuk sebagai 
acuan dalam memperoleh alternatifalternatif yang disusun dalam kerangka hierarki. Alternatif strategi yang telah ditetapkan dinilai oleh responden ahli dengan menggunakan skala 1-9 dengan membuat matrik perbandingan berpasangan (pairwise comparisons). Penentuan perbandingan dilakukan dengan cara judgment pakar. Tingkat konsistensinya ditentukan dengan mendefinisikan nilai perbandingan. Rasio konsistensinya kurang atau sama dari 10 \%. Dalam menentukan strategi pemasaran manggis ditentukan berdasarkan rasio konsistensi tertinggi.

Teknik analisis data yang digunakan dalam penelitian ini adalah dengan menggunakan pendekatan Analytical Hierarchy Process (AHP). Penyusunan strategi yang dilakukan dengan metode Grand Strategi dan pemilihan alternatif solusi yang paling sesuai dilakukan menggunakan AHP. Prinsip kerja AHP adalah menyederhanakan suatu masalah kompleks yang tidak terstruktur, strategik, dan dinamik menjadi bagianbagiannya, serta menata dalam suatu hierarki. Kemudian tingkat kepentingan setiap variabel tersebut secara relatif dibandingkan dengan variabel yang lain. Dari berbagai pertimbangan tersebut kemudian dilakukan sintesa untuk menetapkan variabel yang memiliki prioritas tinggi dan berperan untuk mempengaruhi hasil pada sistem tersebut. Mengetahui strategi pengembangan yang seharusnya dijalankan petani mangis organik di Kabupaten Tasikmalaya, maka dilakukan tahapan kerja pengolahan data dengan menggunakan metode AHP yang terdiri atas:

1) Mendefinisikan permasalahan dan merinci permasalahan tersebut. Mengetahui permasalahan pada suatu kelompoktani di Kabupaten Tasikmalaya dilakukan dengan mempelajari literatur, wawancara dengan responden, dan melakukan observasi di organisasi tersebut untuk mendapatkan konsep yang relevan terhadap permasalahan. Langkah awal yang dilakukan adalah mengidentifikasi dan merinci variabel-variabel yang mempengaruhi strategi pengembangan manggis organik di Kabupaten Tasikmalaya serta keterkaitan antara variabel tersebut, untuk kemudian dijadikan dasar pembuatan hierarki yang memudahkan proses pengolahan data dan interpretasi hasil olahan data.

2) Menyusun matriks banding berpasangan yang merupakan dasar 
untuk melakukan pembandingan berpasangan antar elemen terkait yang berada pada hierarki

\section{HASIL DAN PEMBAHASAN}

\section{Identifikasi Pemasaran Manggis Organik}

Bauran pemasaran merupakan kombinasi dari empat variabel atau kegiatan yang merupakan inti dari sistem pemasaran. Bauran pemasaran meliputi produk, harga, tempat, dan promosi.

\section{Produk}

Produk manggis di kelompoktani Sinar Mustika telah memperoleh sertifikasi organik dari lembaga sertifikasi nasional. Kelompoktani Sinar Mustika merupakan satu-satunya kelompoktani yang mengusahakan dan memasarkan manggis organik yang bersertifikasi. Jenis manggis yang dipasarkan adalah manggis puspahiang yang merupakan buah lokal asal daerah tersebut. Manggis ini memiliki berbagai grade atau tingkatan yakni Grade SP (A) dan Grade BS (B). Perbedaan dua jenis tersebut terletak pada ukuran dan warna kulit. Grade SP memiliki ukuran lebih besar dan warna ungu gelap sempurna dan tidak memiliki jamur. Sedangkan Grade BS ukuran lebih kecil warna ungu kekuningan dan terdapat jamur.
Perbedaan kualitas ini jelas mempengaruhi harga jual dan pangsa pasar. Jumlah manggis pada kelompoktani Sinar Mustika rata-rata menghasilkan 10 ton dalam satu kali masa panen.

\section{Harga}

Penentuan harga manggis di setiap lembaga pemasaran memiliki perbedaan yang cukup siginifikan. Harga manggis di petani untuk kualitas SP memiliki harga sekitar Rp 10.000/kg. Kelompoktani Sinar Mustika hanya sebagai penghubung dengan eksportir. Sehingga tidak menetapkan harga baik dari petani maupun ke eskportir. Eksportir manggis kualitas SP menjual manggis kisaran $\mathrm{Rp}$ 50.00055.000/kilogram namun bisa jatuh dikisaran Rp 16.000/kilogram saat terjadi penurunan permintaan ekspor akibat pandemi. Sedangkan untuk manggis kualitas BS di tingkat petani memiliki

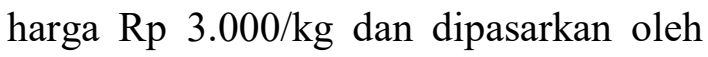
pedagang pengumpul ke pasar induk Kabupaten Tasikmalaya dan sekitar lingkup Priangan. Harga jual manggis di tingkat pengumpul berkisar $\mathrm{Rp}$ $17.000 / \mathrm{kg}$.

\section{Promosi}

Promosi merupakan kegiatan penjualan dan pemasaran dalam rangka 
menginformasikan dan mendorong permintaan dengan cara menarik konsumen untuk membeli produk yang dihasilkan (Rangkuti, 2009). Selama ini kelompoktani Sinar Mustika melakukan kegiatan promosi hanya menggunakan hubungan baik dengan pihak eksportir dan pedagang pengumpul. Kelompoktani Sinar Mustika melakukan penjualan manggis dengan mengandalkan pesanan dari pihak luar.

\section{Distribusi (Place)}

Kegiatan distribusi merupakan kegiatan untuk meningkatkan penjualan dengan memperhatikan proses pengalihan produk dari tangan produsen ke konsumen. Kelompoktani Sinar Mustika tidak melakukan kegiatan distribusi ke pihak luar. Penjualan manggis dilakukan langsung di kebun sendiri dan langsung dilakukan pengangkutan oleh pedagang pengumpul dan eksportir. Petani tidak melakukan penanganan apapun terhadap manggis, hanya melakukan pembersihan di tempat dan sortir di tempat.

Setiap pemasaran terdapat perbedaan peran masing-masing anggota, juga memiliki pola berbeda-beda. Pola tersebut dibangun berdasarkan kemudahan konsumen memperoleh manggis dan upaya untuk menghemat biaya. Menurut Marimin dan Maghfiroh (2010), keberhasilan kelembagaan pemasaran komoditas pertanian tergantung pihak-pihak yang terlibat mampu menerapkan kunci sukses (key succes factor) yang melandasi setiap aktivitas di dalam kelembagaan tersebut. Kunci sukses ini teridentifikasi melalui penelusuran yang detail dari setiap aktivitas didalam rantai pasokan. Kunci sukses tersebut adalah trust building, koordinasi dan kerjasama, kemudahan akses pembiayaan dan dukungan pemerintah.

\section{Identifikasi Faktor Internal dan Eksternal}

Perumusan strategi dengan AHP perlu dilakukan terlebih dahulu identifikasi terhadap faktor internal dan eksternal yang terjadi. Identifikasi ini dilakukan untuk menentukan faktorfaktor apa saja yang menjadi kekuatan dan kelemahan serta peluang dan ancaman yang ada di kelompoktani Sinar Mustika Kecamatan Puspahiang dalam upaya mengembangkan usaha manggis. Setelah faktor-faktor internal dan eksternal diketahui, selanjutnya dibuat dalam bentuk matriks IFE dan EFE untuk melihat bobot prioritas dari masingmasing faktor. Berikut faktor Internal 
dan eksternal pada kelompok tani Sinar

Mustika dalam memasarkan buah manggis terdapat pada Tabel 1 .

Tabel 1. Faktor Internal dan Eksternal Kekuatan (Strength)

1 Hubungan baik antara ketua poktan dengan anggota poktan

2 Memiliki kualitas produk (brand image) yang baik

3 Memiliki pangsa pasar yang luas

4 Hubungan baik dengan pihak eksportir

5 Harga buah manggis terjangkau konsumen lokal dan ekspor

6 Kemudahan akses permodalan

Kelemahan (Weakness)

1 Kurangnya SDM yang berkualitas dalam pemasaran

2 Produk yang mudah rusak

3 Lemahnya akses atau kekuatan pasar

4 Belum memiliki tempat penyimpanan

5 Belum memiliki kegiatan distribusi atau promosi

6 Pembibitan dalam melakukan regenerasi pohon manggis belum dilakukan

7 Kemampuan kelompoktani dalam memanfaatkan teknologi masih kurang

Peluang (Opportunity)

1 Memiliki pasar potensial

2 Meningkatnya gaya hidup sehat

3 Terdapatnya teknologi budidaya manggis

4 Kemudahan memperoleh peralatan pertanian

Ancaman (Threath)

1 Pasar bebas

2 Keberadaan pesaing kelompok usaha sejenis dan sedaerah

3 Serangan hama dan penyakit

4 Cuaca dan iklim yang tidak dapat diprediksi

5 Kebijakan pemerintah terhadap tarif ekspor

6 Daya tawar atau konsinyasi pembeli

sumber: Hasil Penelitian 2020

Hasil pembobotan dapat dilihat

pada Tabel 2.

Tabel 2. Matriks IFE

\begin{tabular}{llll}
\hline $\begin{array}{l}\text { Faktor Strategi } \\
\text { Internal }\end{array}$ & Bobot & Rate & Skor \\
\hline Kekuatan & & & \\
\hline $1 \quad \begin{array}{l}\text { Hubungan baik } \\
\text { antara ketua } \\
\text { poktan dengan } \\
\text { anggota poktan }\end{array}$ & 0,12 & 4 & 0,36 \\
& & & \\
& & &
\end{tabular}

2 Memiliki kualitas

$0,10 \quad 3 \quad 0,15$ produk (brand image) yang baik

3 Memiliki pangsa pasar yang luas

4 Hubungan baik dengan pihak eksportir

5 Harga buah manggis terjangkau konsumen lokal dan ekspor

6 Kemudahan akses $\quad 0,07 \quad 2 \quad 0,14$ permodalan

$\begin{array}{lll}0,11 & 4 & 0,44 \\ 0,12 & 4 & 0,48 \\ 0,09 & 3 & 0,27\end{array}$

Total skor

Kelemahan

1 Kurangnya SDM yang berkualitas dalam pemasaran

2 Produk yang mudah rusak

3 Lemahnya akses $\quad 0,12 \quad 3 \quad 0,36$ atau kekuatan pasar

4 Belum memiliki $\quad 0,03 \quad 2 \quad 0,06$ tempat penyimpanan

5 Belum memiliki kegiatan distribusi atau promosi

6 Pembibitan dalam $\quad 0,02 \quad 1 \quad 0,02$ melakukan regenerasi pohon manggis belum dilakukan

7 Kemampuan kelompoktani dalam memanfaatkan teknologi masih kurang Total Skor Total Faktor Internal 1,00 1,26 $0,09 \quad 2 \quad 0,18$ Berdasarkan hasil matrik IFE pada faktor kekuatan hubungan baik dengan eksportir memiliki skor tertinggi dengan nilai 0,48. Berdasarkan hasil penelitian dengan responden bahwa hubungan dengan eksprtir sangatlah penting dalam kegiatan usaha manggis. Oleh karena itu, 
kelompoktani Sinar Mustika terus melakukan komunikasi dua arah dengan PT Java Fresh dan PT Lalang Buana, terutama hubungan baik dengan PT Lalang Buana yang bisa menerima manggis kualitas SP dan BS. Sedangkan skor paling rendah dalam kekuatan yang dimiliki kelompok Sinar Mustika adalah kemudahan akses permodalan dengan nilai 0,14 . Permodalan dalam kegiatan usaha manggis tidak perlu membutuhkan biaya yang terlalu tinggi. Mengingat kelompoktani tidak melakukan kegiatan distribusi dan promosi ke pihak pembeli. Setelah panen pihak eksportir melakukan pengangkutan dari kebun hasil sortir petani. Sementara itu, pada faktor kelemahan yang dimiliki kelompoktani Sinar Mustika adalah kurangnya SDM dalam bidang pemasaran dengan nilai tertinggi 0,44 . Hal ini terjadi dikarenakan kelompok tani memiliki kekuatan pasar yang rendah dan akses pasar terbatas. SDM yang dimiliki kelompok tani ratarata memiliki pendidikan tingkat pertama bahkan tidak mengenyam pendidikan. Informasi pasar manggis banyak dinikmati oleh pedangan pengumpul dan perusahaan eksportir. Sedangkan kelemahan terendah terletak pada belum melakukan kegiatan distribusi dan promosi dengan nilai skor 0,15 . Hal ini dikarenakan kelemahan ini dapat diatasi dengan hubungan baik dengan eksportir sehingga petani belum memerlukan kegiatan distribusi. Selain itu juga kurangnya modal dalam kegiatan distribusi manggis menjadi faktor petani tidak melakukan kegiatan distribusi produk.

Tabel 3. Matriks EFE

\begin{tabular}{|c|c|c|c|c|}
\hline \multicolumn{2}{|c|}{$\begin{array}{l}\text { Faktor strategi } \\
\text { eksternal }\end{array}$} & Bobot & Rating & Skor \\
\hline \multicolumn{5}{|c|}{ Peluang } \\
\hline 1 & $\begin{array}{l}\text { Memiliki pasar } \\
\text { potensial }\end{array}$ & 0,15 & 4 & 0,6 \\
\hline 2 & $\begin{array}{l}\text { Meningkatnya gaya } \\
\text { hidup sehat }\end{array}$ & 0,11 & 3 & 0,33 \\
\hline 3 & $\begin{array}{l}\text { Terdapatnya } \\
\text { teknologi budidaya } \\
\text { manggis }\end{array}$ & 0,13 & 3 & 0,39 \\
\hline 4 & $\begin{array}{l}\text { Kemudahan } \\
\text { memperoleh } \\
\text { peralatan pertanian }\end{array}$ & 0,09 & 3 & 0,27 \\
\hline \multicolumn{3}{|c|}{ Total skor } & & 1,59 \\
\hline \multicolumn{5}{|c|}{ Ancaman } \\
\hline 1 & Pasar bebas & 0,07 & 4 & 0,28 \\
\hline 2 & $\begin{array}{l}\text { Keberadaan } \\
\text { pesaing kelompok } \\
\text { usaha sejenis dan } \\
\text { sedaerah }\end{array}$ & 0,11 & 4 & 0,44 \\
\hline 3 & $\begin{array}{l}\text { Serangan hama dan } \\
\text { penyakit }\end{array}$ & 0,09 & 1 & 0,09 \\
\hline 4 & $\begin{array}{l}\text { Cuaca dan iklim } \\
\text { yang tidak dapat } \\
\text { diprediksi }\end{array}$ & 0,07 & 2 & 0,14 \\
\hline 5 & $\begin{array}{l}\text { Kebijakan } \\
\text { pemerintah } \\
\text { terhadap tarif } \\
\text { ekspor }\end{array}$ & 0,06 & 3 & 0,18 \\
\hline 6 & $\begin{array}{l}\text { Daya tawar atau } \\
\text { konsinyasi pembeli }\end{array}$ & 0,12 & 2 & 0,24 \\
\hline \multicolumn{3}{|c|}{ Total skor } & & 1,37 \\
\hline & tal faktor eksternal & 1,00 & & 2,96 \\
\hline
\end{tabular}

Berdasarkan hasil matriks EFE pada faktor peluang, memiliki pasar potensial memiliki skor tertinggi dengan nilai 0,6 . berdasarkan hasil wawancara 
dengan pakar responden, manggis dari kelompoktani Sinar Mustika tidak hanya dijual di pasar lokal melainkan ke berbagai daerah bahkan sampai ekspor ke berbagai negara. Sedangkan peluang yang dimiliki Sinar Mustika terendah adalah meningkatnya gaya hidup sehat masyarakat dan kemudahan memperoleh peralatan dengan skor 0,27. Hal ini dikarenakan buah manggis puspahiang lebih eksis pada pasar ekspor tanpa melihat perubahan gaya hidup masyarakat.

Sedangkan untuk faktor ancaman yang memiliki skor tertinggi terdapat pada keberadaan kelompok usaha sejenis dan sedaerah dengan skor 0,44 . Terutama pesaing pedangan pengumpul yang jumlahnya tidak sedikit dalam satu desa. Hal ini menyebabkan kelompoktani Sinar Mustika memperoleh persaingan harga yang cukup kuat. Petani tidak memiliki kemampuan untuk menentukan harga jual. Sedangkan ancaman terendah terdapat pada serangan hama dan penyakit dengan nilai skor 0,09 . Hal ini dikarenakan tanaman manggis memiliki daya tahan yang cukup kuat terhadap hama dan penyakit.

Hasil perhitungan faktor internal dan eksternal digunakan untuk menentukan titik koordinat strategi yang dapat dilakukan. Sumbu horizontal (X) merupakan faktor internal dengan nilai koordinat $\mathrm{X}$ adalah selisih faktor kekuatan dikurangi faktor kelemahan. Sedangkan untuk sumbu horizontal (Y) merupakan faktor eksternal yang merupakan pengurangan dari peluang dan ancaman. Berdasarkan hasil perhitungan tersebut maka diperoleh sumbu $X(1,84-1,26)=0,58$. Sedangkan untuk sumbu Y $(1,59-1,37)=0,22$.

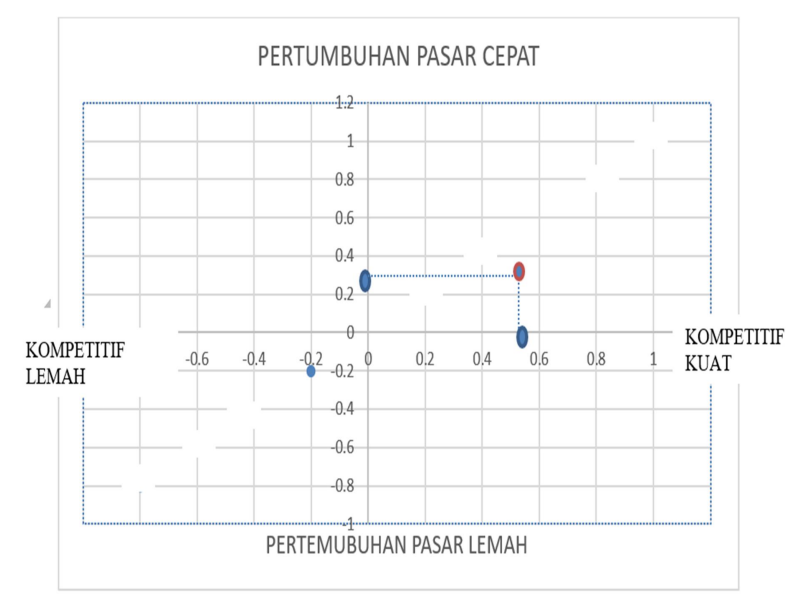

Gambar 1. Posisi Kuadran Grand Strategi

Berdasatkan posisi kuadran di atas menunjukkan bahwa kelompok tani Sinar Mstika berada pada koordinat kuadran 1 atau posisi kompetitif kuat dan pertumbuhan pasar cepat. Pada posisi ini pemasaran manggis di kelompoktani Sinar Mustika di Kabupaten Tasikmalaya memiliki kekuatan yang lebih besar dibandingkan kelemahan dan memiliki peluang yang lebih besar dibandingkan ancaman yang ada. Kelompoktani 
bersama dengan petani harus terus berkontribusi pada pasar manggis dengan terus menngembangkan pasar potensial dan memperkenalkan manggis puspahiang ke wilayah baru dengan memanfaatkan hubungan baik dengan eksportir agar dapat menjangkau pasar yang lebih luas.

\section{Strategi Pemasaran Manggis dengan dengan AHP}

AHP merupakan alat analisis yang dapat digunakan untuk menentukan beberapa alternatif pilihan dari beberapa alternatif yang tersedia (Hefnawi dan Mohamed, 2014). Berdasarkan hasil penelitian kami dengan beberapa ahli manggis maka dalam merumuskan strategi pemasaran tidak terlepas dari bauran pemasaran yaitu 4P (Place, Product, Promotion, dan Price). Selanjutnya terdapat 5 alternatif strategi yang diperoleh berdasarkan hasil Grand Strategy yang ditentukan langsung oleh pakar. Berikut alternatif strategi yang dirumuskan terdapat pada Tabel 4.

Tabel 4. Alternatif Strategi

\begin{tabular}{cl}
\hline Kode & Alternatif Strategi \\
\hline 01 & $\begin{array}{l}\text { Meningkatkan pangsa pasar dengan } \\
\text { menjalin kerjasama dengan berbagai } \\
\text { pihak }\end{array}$ \\
02 & $\begin{array}{l}\text { Melakukan kegiatan distribusi dalam } \\
\text { proses pemasaran }\end{array}$ \\
03 & $\begin{array}{l}\text { Peningkatan kualitas manggis } \\
\text { pascapanen }\end{array}$ \\
04 & $\begin{array}{l}\text { Penyediaan industri pengolahan } \\
\text { manggis }\end{array}$
\end{tabular}

05 Pengembangan pasar dengan teknologi digital

Berdasarkan Hasil analiis AHP pada bauran pemasaran 4P menunjukkan kriteria yang menjadi prioritas dalam pemasaran adalah promosi yang ditekankan pada mempeluas pangsa pasar dengan nilai bobot prioritas $0 . .42$. Hal ini dikarenakan kelompoktani memiliki keterbatasan dalam akses pasar dan kelemahan dalam penentuan harga jual bahkan informasi pasar dari luar. Sedangkan prioritas terendah pada produk dengan nilai bobot 0.12 . Hal ini dikarenakan produk manggis yang dipasarkan telah memiliki kualitas yang baik dan diterima oleh konsumen lokal dan ekspor. Prioritas paling penting adalah pengolahan pascapanen yang diketahui petani manggis memiliki nilai jual lebih tinggi. Bobot kriteria AHP terdapat pada Tabel 5.

Tabel 5. Bobot Kriteria AHP

\begin{tabular}{clc}
\hline Peringkat & Kriteria & Bobot AHP \\
\hline 1 & Promotion & 0,42 \\
2 & Price & 0,25 \\
3 & Place & 0,21 \\
4 & Product & 0,12 \\
\hline
\end{tabular}

Berdasarkan Hasil analisis AHP pada bauran pemasaran 4P menunjukkan kriteria yang menjadi prioritas dalam pemasaran adalah promosi yang ditekankan pada mempeluas pangsa pasar dengan nilai bobot prioritas 0,42 . 
Hal ini dikarenakan kelompoktani memiliki keterbatasan dalam akses pasar dan kelemahan dalam penentuan harga jual bahkan informasi pasar dari luar. Sedangkan prioritas terendah pada produk dengan nilai bobot 0.12 . Hal ini dikarenakan produk manggis yang dipasarkan telah memiliki kualitas yang baik dan diterima oleh konsumen lokal dan ekspor. Prioritas paling penting adalah pengolahan pascapanen yang diketahui petani manggis memiliki nilai jual lebih tinggi.

Tabel 6. Bobot Kriteria AHP

\begin{tabular}{clc}
\hline Peringkat & Kriteria & Bobot AHP \\
\hline 1 & Promotion & 0,42 \\
2 & Price & 0,25 \\
3 & Place & 0,21 \\
4 & Product & 0,12 \\
\hline
\end{tabular}

Dari berbagai kriteria dan alternatif strategi yang telah ditetapkan maka struktur hirarki AHP dalam penentuan strategi pemasaran manggis terdapat pada Gambar 2.

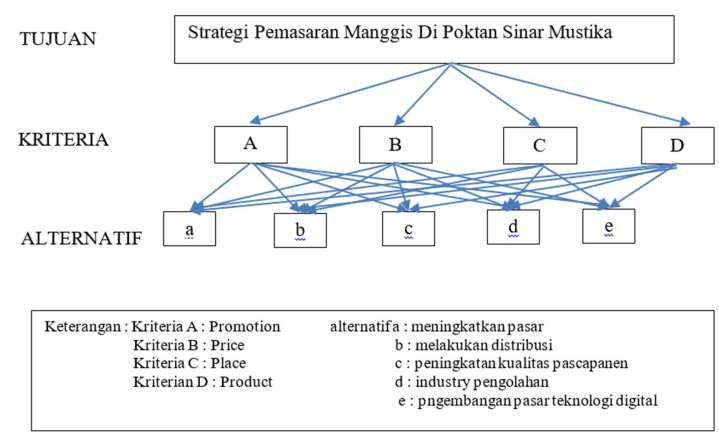

Gambar 2. Struktur Hirarki AHP Pemasaran Manggis
Pemasaran yang sedang dikembangkan oleh kelompoktani saat ini adalah sistem penjualan manggis di pasar lokal dan nasional dengan melibatkan lembaga keuangan desa dalam penyedia modal transportasi. Hal ini untuk memperluas pangsa pasar yang tidak hanya melibatkan dua perusahaan. Petani dapat langsung memasarkan produknya ke konsumen tingkat akhir dengan harga yang lebih tinggi setelah melakukan sortir. Aspek pemasaran manggis yang paling penting adalah transportasi atau distribusi dan harga yang terjangkau.

Tabel 7. Bobot Alternatif Strategi Berdasarkan

\begin{tabular}{clc}
\multicolumn{3}{c}{ Promosi } \\
\hline Peringkat & Alternatif Strategi & Bobot AHP \\
\hline 1 & $\begin{array}{l}\text { Meningkatkan } \\
\text { kerjasama dengan } \\
\text { berbagai pihak }\end{array}$ & 0,48 \\
2 & $\begin{array}{l}\text { Peningkatan kualitas } \\
\text { manggis pascapanen }\end{array}$ & 0,25 \\
3 & $\begin{array}{l}\text { Melakukan distribusi } \\
\text { Pengembangan pasar } \\
\text { teknologi digital }\end{array}$ & 0,23 \\
5 & $\begin{array}{l}\text { Penyediaan industri } \\
\text { pengolahan manggis }\end{array}$ & 0,01 \\
\hline
\end{tabular}

Penentuan alternatif strategi dilihat dari kriteria promosi menunjukkan hasil alternatif strategi meningkatkan kerjasama dengan berbagai pihak memiliki nilai tertinggi dengan nilai bobot prioritas 0,48. Hal ini perlu dilakukan untuk menambah atau mengembangkan pangsa pasar manggis. Kelompoktani Sinar Mustika perlu 
melakukan komunikasi dengan membuka hubungan baik dengan berbagai pihak. Mengingat belum memiliki kotrak kerjasama dengan pihak manapun, maka kelompoktani Sinar Mustika harus berani mengambil langkah baru untuk membuka pasar. Sedangkan untuk alternatif strategi dalam kegiatan promosi terletak pada penyediaan industri pengolahan manggis dengan bobot 0,03 . Berdasarkan wawancara dengan berbagai ahli bahwa kelompok tani sinar mustika belum memperoleh pendidikan serta pelatihan mengenai cara pengolahan manggis menjadi sebuah produk yang bernilai jual tinggi.

Tabel 8. Bobot Alternatif Strategi Berdasarkan

\begin{tabular}{clc}
\multicolumn{3}{c}{ Harga } \\
\hline Peringkat & Alternatif Strategi & Bobot AHP \\
\hline 1 & $\begin{array}{l}\text { Peningkatan } \\
\text { kualitas manggis } \\
\text { pascapanen }\end{array}$ & 0,37 \\
& $\begin{array}{l}\text { Melakukan } \\
\text { distribusi }\end{array}$ & 0,35 \\
3 & $\begin{array}{l}\text { Peningkatan } \\
\text { kerjasama dengan } \\
\text { berbagai pihak } \\
\text { Pengembangan } \\
\text { pasar teknologi } \\
\text { digital } \\
\text { Penyediaan } \\
\text { industri } \\
\text { pengolahan } \\
\text { manggis }\end{array}$ & \\
& 0,091 \\
& 0,009 \\
\end{tabular}

Hasil alternatif strategi dilihat dari kriteria harga menunjukkan alternatif strategi tertinggi terletak pada kode 03 dengan nilai bobot 0,37 . Alternatif strategi yang harus dilakukan adalah peningkatan kualitas manggis pascapanen. Hal ini perlu dilakukan oleh kelompoktani dengan melakukan pembersihan dan sortir terhadap buah yang akan dipasarkan sebelum diterima pihak eksportir atau pedagang pengumpul lainnya. Sedangkan alternatif strategi terendah pada kode 04 dengan bobot 0,009 terletak pada penyediaan industri pengolahan manggis.

Tabel 11. Alternatif Strategi Berdasarkan Kriteria Tempat

\begin{tabular}{clc}
\hline Peringkat & Alternatif Strategi & Bobot AHP \\
\hline 1 & $\begin{array}{l}\text { Melakukan } \\
\text { distribusi }\end{array}$ & 0,46 \\
2 & $\begin{array}{l}\text { Peningkatan } \\
\text { kualitas pascapanen }\end{array}$ & 0,28 \\
3 & $\begin{array}{l}\text { Peningkatan } \\
\text { kerjasama dengan } \\
\text { berbagai pihak }\end{array}$ & 0,15 \\
& $\begin{array}{l}\text { Penyediaan Industri } \\
\text { pengolahan } \\
\text { manggis }\end{array}$ & 0,08 \\
& $\begin{array}{l}\text { Pengembangan } \\
\text { pasar teknologi } \\
\text { digital }\end{array}$ & 0,03 \\
& &
\end{tabular}

Berdasarkan hasil alternatif strategi pada kriteria tempat diperoleh strategi tertinggi pada kode 02 dengan nilai bobot 0,46 . Menunjukkan bahwa penetapan strategi yang paling tepat dalam kriteria tempat adalah melakukan distribusi ke pasar. Berdasarkan wawancara dengan pakar menyebutkan bahwa untuk tempat pemasaran yang menjadi target strategi adalah kelompoktani dapat melakukan distribusi langsung ke pasar tanpa adanya perantara. Sehingga saat panen melimpah dan permintaan turun dapat diantisipasi dengan kegiatan distribusi langsung 
dengan pasar yang tepat. Sedangkan alternatif strategi terendah dalam menentukan tempat pemasaran terletak pada kode 05 adalah pengembangan dengan media digital. Hal ini dikarenakan belum adanya petani paham mengenai pemasaran media digital atau online.

Tabel 12. Alternatif Strategi Berdasarkan Kriteria

\begin{tabular}{|c|c|c|}
\hline Peringkat & Alternatif Strateoi & Bobot AHP \\
\hline 1 & $\begin{array}{l}\text { Peningkatan kualitas } \\
\text { pasca panen }\end{array}$ & 0,39 \\
\hline 2 & $\begin{array}{l}\text { Penyediaan industri } \\
\text { pengolahan manggis }\end{array}$ & 0,35 \\
\hline 3 & $\begin{array}{l}\text { Pengembangan pasar } \\
\text { teknologi digital }\end{array}$ & 0,20 \\
\hline 4 & Melakukan distribusi & 0,04 \\
\hline 5 & $\begin{array}{l}\text { Peningkatan } \\
\text { kerjasama dengan } \\
\text { berbagai pihak }\end{array}$ & 0,02 \\
\hline
\end{tabular}

Hasil alternatif strategi pada kriteria produk dengan bobot tertinggi terdapat pada strategi kode 03 dengan nilai bobot 0,39 . Alternatif strategi yang harus dilakukan pada produk adalah peningkatan kualitas pascapanen. Berdasarkan wawancara dengan pakar manggis, bahwa dalam pemasaran manggis diperlukan kualitas yang baik terutama untuk pasar ekspor. Butuhnya penanganan yang sangat baik dalam pengemasan buah manggis, bentuk manggis, kulit manggis dan warna manggis dalam menarik konsumen lokal dan ekspor. Sedangkan alternatif strategi terendah terdapat pada kode 01 dengan bobot 0,02 yaitu peningkatan kerjasama dengan berbagai pihak. Berdasarkan hasil wawancara dan analisis pada produk manggis belum memerlukan penanganan melalui kerjasama. Dikarenakan produk yang dijual merupakan produk utuh yang banyak dicari perusahaan farmasi dan pedagang besar lainnya.

Tabel 13. Bobot Seluruh Alternatif

\begin{tabular}{clc}
\hline Peringkat & Alternatif Strategi & Bobot AHP \\
\hline 1 & $\begin{array}{l}\text { Peningkatan kualitas } \\
\text { pasca panen }\end{array}$ & 0,32 \\
2 & $\begin{array}{l}\text { Melakukan distribusi } \\
\text { Peningkatan }\end{array}$ & 0,27 \\
3 & $\begin{array}{l}\text { kerjasama dengan } \\
\text { berbagai pihak }\end{array}$ & \\
& Penyediaan industri & 0,13 \\
4 & $\begin{array}{l}\text { pengolahan } \\
5\end{array}$ & $\begin{array}{l}\text { Pengembangan pasar } \\
\text { teknologi digital }\end{array}$ \\
\end{tabular}

Hasil analisis terhadap 5 alternatif strategi terhadap pemasaran manggis maka alternatif strategi yang harus dilakukan pertama kali oleh kelompoktani Sinar Mustika adalah peningkatan kualitas pascapanen. Berdasarkan wawancara dengan para pelaku usaha manggis terutama untuk kelompoktani Sinar Mustika memang belum adanya peningkatan kualitas yang dilakukan oleh petani. Proses penanganan pascapanen selama ini dimanfaatkan oleh pedagang pengumpul dan pihak eksportir. Oleh karena itu, perlu adanya upaya dari kelompoktani dalam menjaga kualitas manggis dan melakukan kegiatan sortir dengan baik. 
Sedangkan bobot terendah dalam alernatif strategi berada pada pengembangan pasar teknologi digital. Pada dasarnya pemerintah setempat telah melakukan upaya untuk mengembangkan desa digital dengan kemudahan akses jaringan. Namun akses tersebut belum dapat dimanfaatkan petani manggis dikarenakan belum memiliki alat elektronik untuk kegiatan komunikasi dan akses internet. Upaya yang harus dilakukan kelompoktani Sinar Mustika adalah meneruskan jaringan komunikasi kepada seluruh anggota agar dapat menerima informasi yang jelas.

\section{KESIMPULAN DAN SARAN}

Berdasarkan analisis saluran pemasaran manggis di Kelompok tani Sinar Mustika maka terdapat 3 saluran pemasaran dengan melibatkan dua perusahaan besar, yaitu PT. Java Fresh dan PT Lalang Buana. Aktivitas setiap pelaku pemasaran manggis memiliki kesamaan dengan melakukan sortir dan pembersihan. Bahkan petani manggis tidak melakukan sepenuhnya kegiatan usahatani melainkan hanya melakukan pemupukan dan pemanenan. Pelaku usaha yang paling berpengaruh adalah pihak eksportir dengan berbagai proses penanganan sebelum dipasarkan.
Hasil analisis internal eksternal bahwa kelompoktani sinar mustika dalam memasarkan manggis memiliki kekuatan yang lebih tinggi dibandingkan kelemahan dan peluang tinggi dibandingkan ancaman. Hal ini menggambarkan posisi Kelompoktani Sinar Mustika berada pada posisi dengan pertumbuhan cepat dan kompetitif kuat. Hal ini digunakan sebagai dasar dalam penentuan alternatif strategi AHP.

Berdasarkan hasil analisis internal dan eksternal diperoleh 5 alternatif strategi yang digunakan dalam hirarki AHP. Alternatif strategi tersebut digunakan untuk meningkatkan pemasaran manggis pada kelompok tani Sinar Mustika dalam melihat bauran pemasaran 4P. Hasil dari 5 alternatif strategi yang ada maka strategi peningkatan kualitas yang menjadi prioritas dengan bobot 0,32. Proses peningkatan kualitas dilakukan manggis agar memperoleh harga jual lebih tinggi dan mengundang konsumen untuk memperoleh manggis dari kelompoktani Sinar Mustika.

\section{DAFTAR PUSTAKA}

Ariani SS, Diana Chalil, dan Emalisa. 2013. Startegi Pengembangan Sistem Agribisnis Beras Organik di Kecamatan Perbaungan Kabupaten Serdang Bedagai Sumatera Utara. 
Jurnal Universitas Sumatera Utara Program Studi Agribisnis Fakultas Pertanian USU. Sumatera Utara.

Assauri. SA. 2013. Strategic Marketing Sustaining Lifetime Customer Value. Depok (ID) : PT Raja Grafindo Persada.

Asmarantaka RW. 2012. Pemasaran Agribisnis (Agrimarketing). Departemen Agribisnis. Fakultas Ekonomi dan Manajemen. Institut Pertanian Bogor.

Duasa J. 2011. Terms or Trade and Economic Growth : An Estimate of the Threshold Level of Terms of Trade for Malaysia. International Journal of Economic Perpective. Vol 5 (1). Pp 29-43
Ferrianta Y, N Hanani B, Setiawan WM. 2012. Impact of Trade Liberalization Asean-China Free Trade Area (ACFTA) on The Performance of Indonesia Maize Economy. Journal of Basic and Applied Scientific Research, Vol 2(7). Pp.6801-6809.

Firdaus M. 2009. Daya Saing dan Sistem Pemasaran Manggis Indonesia. Bogor : Fakultas Ekonomi dan Manajemen. Institut Pertanian Bogor.

Garate SE, Steenkamp W, Viviers \& L Cuyvers. 2015. Combining the Export Promotion of Products and Services The Case of South Africa Southern African Business Review 18 (3). 93-118. 